\title{
“Jewelry by Foot Locker: One Step Beyond"
}

\section{Miriam Roberts, ANN Inc.}

USA

\section{Herbert Sherman, Ph.D.}

Professor

Department of Business

School of Business, Public Administration and Information Systems

Long Island University

Email: Herbert.Sherman@liu.edu

USA

\section{ABSTRACT}

Foot Locker Inc. is known globally for its athletic shoes and apparel and has the brand identity to leverage its name by diversifying into other product lines. Foot Locker wants to be known for more than just a "sneaker spot", but they are missing that extra component or accessory that would broaden their brand image. Men go to Foot Locker locations for shoes and apparel, but their outfit is still not complete since it lacks one necessity-jewelry. Men mostly get their jewelry online or from major department stores. What if Foot Locker could fill in that void? This article analyzes Foot Locker relative to the men's accessories market. Jewelry is the oldest way of expression and combined with sneakers, it could be Foot Locker's ticket to growth and continued success. We will discuss the possibility of Foot Locker starting their jewelry product extension that will be targeting their already known male demographic. Through the application of market research, creating an assortment plan, and global market research it is hypothesized that Jewelry by Foot Locker could become a great addition to the Foot Locker brand. If done properly, this jewelry extension could be the newest way Foot Locker improves their image and profits.

\section{INTRODUCTION}

In 1963, the F.W. Woolworth Company purchased the Kinney Shoe Corporation and operated it as a subsidiary." In the 1960s, Kinney branched into specialty shoe stores, including Stylco in 1967, Susie Casuals in 1968, and Foot Locker on September 12, 1974, in Puente Hills Mall in City of Industry. (Foot Locker, 2/7/20).

The rest was history. Foot Locker was founded in 1989 and its headquarters is in New York, NY. Foot Locker is the number one retailer for athletic shoes and apparel. They operate not only through their Foot Locker brand but other brands as well. These brands include Foot Locker, Lady Foot Locker, Kids Foot Locker, Champ Sports, Six 02, Footaction, and CCS. These brands especially, Foot Locker, sell numerous products for all types of sports including football, basketball, soccer, volleyball, etc. Besides selling merchandise for sports activities, Foot Locker also sells shoes for fashion and style. They sell other brands besides their own including Converse, Vans, Reebok, Nike, Puma, Adidas, and Jordan's.

Even though Foot Locker is a great retailer that appears to be thriving, even in a COVID environment, they have the growth potential. As of 2019, "the company net income decreased to $\$ 498$ million to 2019 , as compared to the
2018 net income of $\$ 541$ million." (Foot Locker, 2/28/20) and therefore a product brand extension might be quite timely in offsetting the near $8 \%$ drop in net income. "Foot Locker, the largest U.S. specialty athletic-shoe retailer no longer wants you to think of it as a just a sneaker shop" (Cheng, 2019) and therefore expanding their brand name to new products and services would be quite appropriate.

We are proposing that "Jewelry by Foot Locker" would be a great opportunity to leverage Foot Locker's male demographic and complete their customer's clothing ensemble. Patrons will be able to get apparel, shoes, and, now jewelry and will therein not need to go to multiple stores to get a complete outfit. Not only will meet the current customer base needs for accessories but this offering may attract new customers to Foot Locker who normally would not shop there. Once the new client has walked in the door (real or virtual) the possibilities of bundling the jewelry with clothing and sneakers may heighten sales.

The Challenge. Are men going to buy jewelry where they buy their clothes and shoes? Jewelry by Foot Locker is going to offer an assortment of jewelry for their men demographic but the staple piece that they are mainly going to sell in this collection is gold and silver chains. "Usage of gold chains and necklaces is no longer limited to weddings and 
functions. Men wear rings, plain gold chains, and anklets as a fashion statement." (Grand View Research, 2019). Foot Locker's main goal when they drop this collection is to see if the first men are attracted to buy jewelry with their sneakers and apparel that Foot Locker has to offer.

\section{Market Research}

When you think about the sneaker industry and how they're doing right now, they're performing pretty well. "Global sneakers market stood at $\$ 58$ billion in 2018 and is projected to grow at over 7\% during 2019-2024 to reach $\$ 88$ billion by 2024." (ReportBuyer, 2019). Whether it be for sports activities or just for fashion, sneakers are constantly being bought and worn. They are used not only for functional purposes but as a form of an expression-the unique style that the customer wants to use as part of his self-image. Sneakers in 2020 represent a person's style and is an expression of who they are.

Technology and social media have buttressed industry growth. Entrepreneurs can use places like Facebook, Craig's List, Instagram, eBay, etc. to start their business and notify people that they have the sneakers they want. There is even a market segment dedicated to buying and reselling sneakers. Resellers buy a certain amount of the hottest sneakers that people want and later cannot obtain due to stock-outs and then resell these sneakers for a high profit.

Foot Locker is known for coming out with different collaborations with various sneakers brands which makes customers have to have them as well. For example, different celebrities might come out with different sneakers that make it more enticing to want such as known music artists like, Cardi B x Reebok, Pharrell x Puma, Travis Scott x Air Jordan 1. Foot Locker customers look up to these celebrities, so they are going to want any quality merchandise that these celebrities endorse.

The jewelry industry, because of social media, influencers, and fashion trends, has increased over the past few years although there has always been a jewelry market. "Jewelry is one of the most ancient and enduring forms of personal expression and ornamentation." (O'Connell, 2020). People have been using jewelry to express where they come from, who they are, and where they want to be. It is a form of status and wealth. "The value of the jewelry market is expected to increase from about 279 billion U.S. dollars in 2018 to about 480.5 billion dollars by 2025." (O'Connell, 2020). The projected growth of this industry bodes well for Foot Locker when coupled with the projected growth of the sneaker industry. Sneakers and jewelry work well together because there are no set standards on how to simultaneously wear them and customers can use both to express their individuality. As Foot Locker's tagline is "Foot Locker always comes through" (Velasco, 2017). They can come through with the personalization, expression, and individuality when they offer a jewelry line that matches their current offerings.

\section{Consumer Behavior and Fashion Retail Management}

The target market that Foot Locker should go after first for this product extension is young males. The sneaker industry and Foot Locker especially is a "guy" industry. Men collect and show their style through what they wear which is sneakers. The specific target market they should go after is men between the ages of 21-30. They could be single, dating or married, are attending or graduated from college, and now are working part-time or even a full-time job. In their spare time, these young men enjoy going to social events like parties and dress up by wearing sneakers and jewelry such as chains. These men historically (pre-COVID) have liked to go to the shopping mall and shop for sneakers. They grew up with technology, however, so they have social media accounts with Instagram, Twitter, and Facebook where they now purchase products and services. They may follow athletes on these accounts, and they watch sports on the weekends with their friends. These men like to dress sporty, modern, dressy, or laid back. This group of individuals all like to wear sneakers with their chains, earrings, brace, lets, or pendant necklaces.

"Bronto's 2015 Consumers Tell All survey said that nearly a third of men nationwide (30\%) report shopping ecommerce sites weekly." (Murphy, 2015) The rest of the time this market segment likes to shop more in-store than online so they can see how the sneaker looks in person. "Men are information seekers; research each product they want in-depth and look at all the features of the product." (Adglow, 2020). So, in their spare time, these men are on their smartphones and the internet looking at the sneakers they want, their features including how they may look on other people. That way they can go to Foot Locker and know exactly what they want before they come to the store. Men also spend more money on themselves than women so Foot Locker, a benefit Foot Locker can leverage. "Men spend 10 euros (11.84 United States dollars) on each purchase more than women." (Adglow, 2020).

Foot Locker Customer Analysis. "According to a 2018 survey, over $23 \%$ percent of respondents, aged 18-29 years, stated that they had shopped for shoes in person at Foot Locker in the last 12 months." (O'Connell, 2020). The first demographic that Jewelry by Foot Locker is going to go after first is males. This type of demographic values style, status, and making a statement. "Studies show to make male shoppers look twice, you need to show them value for their money, more than lure them in with the fancy brand." (Lesonsky, 2020). They go to Foot Locker to get their shoes and apparel. Now they will be able to go to Foot Locker to get a piece of jewelry to complete their outfits. Jewelry by Foot Locker will the great quality jewelry at great prices that will make the male demographic want to shop there rather than Foot Locker's 
competitors. Male shoppers also value deals and long-term loyalty. So, the more that they shop with Foot Locker the more deals and rewards they can get with the store which in return is going to get them to come back for more. The three types of consumers driving the growth of the jewelry industry are first the "new money consumers". "They wear branded jewelry to show off their newly acquired wealth." (Dauriz, Remy, and Tochtermann 2014). The emerging-market consumers are consumers that trust and have an upgraded lifestyle. Lastly, young consumers are the ones who look for brands that are going to encourage and help them in their self-expression and self-realization. The young consumers are the ones that are going to be the main customer's Jewelry by Foot Locker will be targeting.

Given these young consumers, the proposed Foot Locker jewelry's extension will be available on all Foot Locker platforms that would normally be used to purchase both online, in-store including the Foot Locker mobile application. In that way, the target market can always stay abreast of the new jewelry offerings that are coming out on multiple platforms. While the customers are in-store, they can visually look at the cases, see mannequins wearing the jewelry and see what the jewelry looks like. While they are browsing online or on their smartphone, they can see pictures of what the jewelry looks like and what it looks like on display models.

\section{Merchandise Assortment}

Below is an example of the assortment plan Foot Locker jewelry could offer. This includes chains (silver and gold), Jesus pendants, silver earrings, rings, and watches. The main two products that are going to sell are an assortment of chains. Chains are the stable of the extension, a must-wear for this target market, and that is why they have been forecasted to sell the most units. The assortment plan is quite basic and is meant to be refined based on performance in-store and online sales. Once Foot Locker launches the jewelry line, they can adjust the assort line and product mix. Once established Foot Locker can expand to more designs, styles, and customer personalization.

Visually, Foot Locker can have two options and use one or both options when it comes to how they want their store to look. They can first have a separate jewelry store that they can attach to their existing Foot Locker locations and customers can go to and from both stores. The store will look like the one pictured below, see Figure 2, a more upscale look for Foot Locker.

\section{MERCHANDISING PLAN}

\begin{tabular}{|c|c|c|c|c|c|c|}
\hline classification & units & $\%$ to total & Sales \$ & $\%$ to total & average price $\begin{array}{c}\% \text { increase units } \\
\text { (YOY) }\end{array}$ \\
\hline & & & & & & \\
\hline Gold Chains & 1000 & $27.4 \%$ & $\$ 220,000$ & $14.0 \%$ & $\$ 220$ & $900.0 \%$ \\
\hline Silver Chains & 800 & $21.9 \%$ & $\$ 160,000$ & $12.74 \%$ & $\$ 200$ & $186 \%$ \\
\hline Jesus Pendants & 750 & $20.5 \%$ & $\$ 262,500$ & $22.29 \%$ & $\$ 350$ & $200 \%$ \\
\hline Silver Earrings & 600 & $16.4 \%$ & $\$ 120,000$ & $12.74 \%$ & $\$ 200$ & $500 \%$ \\
\hline Rings & 100 & $2.7 \%$ & $\$ 20,000$ & $12.74 \%$ & $\$ 200$ & $-23 \%$ \\
\hline Watches & 400 & $11.0 \%$ & $\$ 160,000$ & $25.48 \%$ & $\$ 400$ & $400 \%$ \\
\hline & & & & & & \\
\hline & & & & & & \\
\hline & 3650 & $100.0 \%$ & $\$ 942,500$ & $100 \%$ & $\$ 1,570$ & $288.3 \%$ \\
\hline & & & & & & \\
\hline & & & & & & \\
\hline
\end{tabular}

Figure 1 Proposed Merchandising Plan for Foot Locker

Separate Attached Store. The above-attached store is going to have more of a showcase feel with limited jewelry in the actual cases and more in the backroom. Each case will be separated by brand and style. Customers will be able to walk through the jewelry section into the Foot Locker section. That way they can grab footwear and a piece of jewelry to match right afterward. There will need to be trained and specialized sales associates that will be able to help the customers with the type of jewelry they are looking for since jewelry is a specialized accessory that the current sales associates may not be familiar with. If a sales associate sees that the customer just brought some footwear and clothing from Foot Locker, he or she will be able to tell them the best jewelry that goes well with their outfit. The walls will have interactive mirrors where 


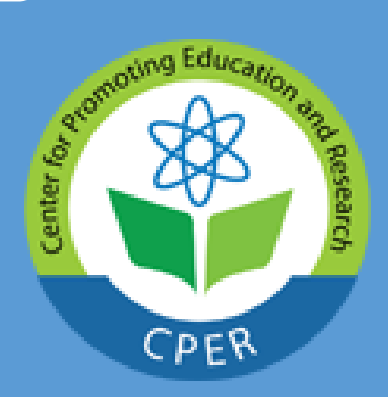

International Journal of Business and Applied Social Science (IJBASS)

E-ISSN: 2469-6501

VOL: 6, ISSUE: 11

November/2020

DOI: 10.33642/ijbass.v6n11p1

\section{(C) Center for Promoting Education and Research (CPER) USA}

www.cpernet.org

customers can see all the jewelry options provided by Foot store including responses to any of the products discussed in Locker and what footwear and clothing match the collection. the reviews.

Customer reviews will also be available both online and in-

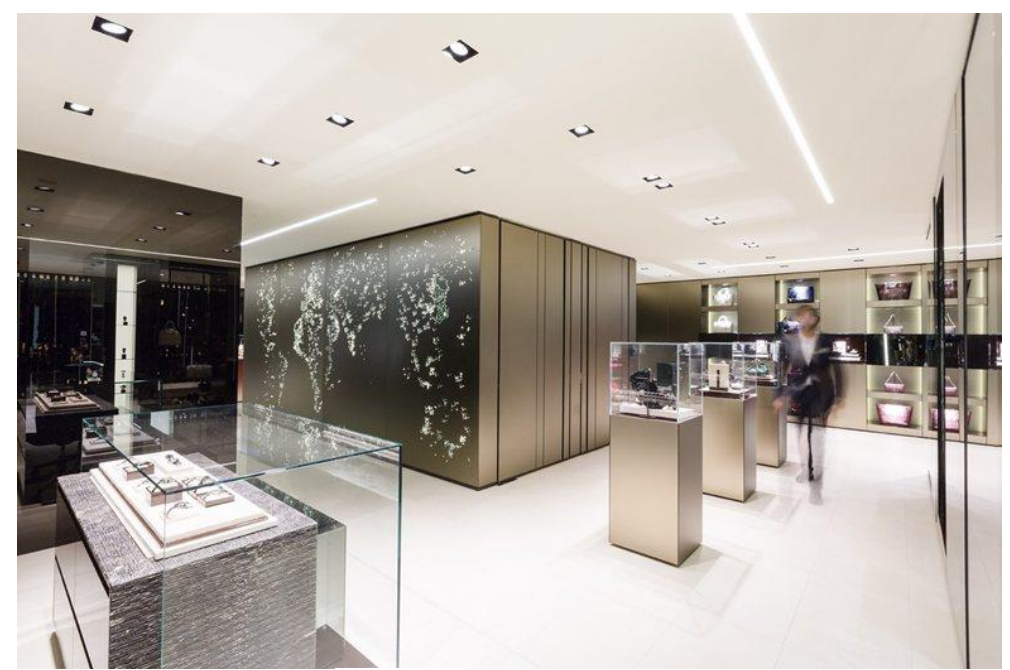

Figure 2

Proposed Foot Locker Stand-Alone Jewelry Store

In-store Jewelry Section. The second option is to have all depends on the location of the store and the visual a jewelry section in their existing Foot Locker locations and to experiences they are trying to provide. Both options show the display the jewelry on the mannequins currently wearing jewelry assortment and are going to get the attention of the clothing and sneakers. They can dress the mannequins like targeted male demographic.

they're going out or in athletic gear. (See Figure 3 below.) It
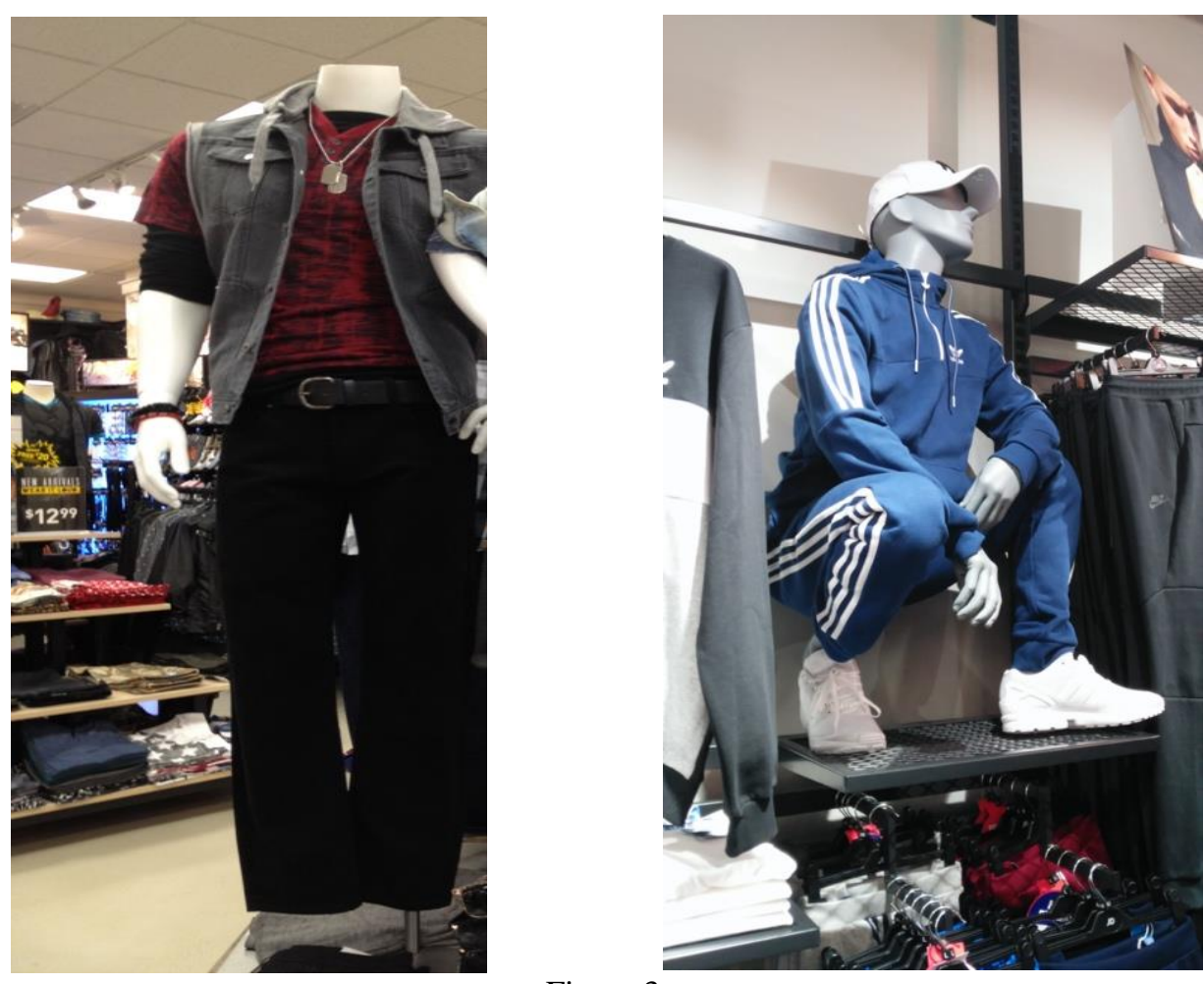

Figure 3

Proposed Foot Locker Mannequin Displays Wearing Clothing \& Jewelry 
E-ISSN: 2469-6501

VOL: 6, ISSUE: 11

November/2020

DOI: 10.33642/ijbass.v6n11p1

\section{(C) Center for Promoting Education and Research (CPER) USA}

WWW.cpernet.org

\section{Technology in Fashion Merchandising and Management}

Technology is not a far concept when it comes to Foot Locker. They have been working over the years to better their Omnichannel sales and supply channel throughout their company. "Foot Locker said it's using RFID to track in-store inventory and is studying data to better come up with personalized products and marketing that consumers want and demand instead of its traditional approach." (Cheng, 2019).

The jewelry assortment will use the same technology. Customers will be able to shop in-store, online, using any smart device, and on social media accounts. The jewelry will also have RFID tags to track inventory and indicating which products are selling successfully and not. Patrons will also be able to call customer service on the phone if they need any help or concerns about their orders or products in general. When shopping online consumers will have the option of shipping purchases to their homes or picking up in-store. All of these channels will be connected so there will be a seamless experience. With a simple email and name, Foot Locker will be able to look up customers' past transactions, search history, and merchandise that 'looked at' but not purchased. Foot Locker can use this knowledge to better promote and target this demographic.
Below (Figure 4) is a picture of how the website is going to look when a shopper goes on Foot Locker's landing page. The images of the jewelry are going to modern and realistic so the men's target market can relate and see themselves wearing the products. When the jewelry collection comes out, it is going to be on the main Foot Locker page. There, the men can click on the image and it will take them to a new page that is going to have the entire collection including images with models on how they look.

Foot Locker's main website page is going to showcase the new jewelry that comes out with the pricing and locations of where to find them in-store. There will also be an interactive feature where men can see how it looks on themselves or with a pair of sneakers. Foot Locker will also show pictures of actual customers and how they paired the specific pieces of jewelry with apparel or sneakers from Foot Locker. That way the customers can get an idea of how they may want to style it themselves. As the collection expands, there will be more features added to the website as well. Big Data is also going to help clients experience a seamless Omnichannel experience because Foot Locker is going to know what does and doesn't work when it comes to this jewelry line. Whatever a customer may need or want, they will know about it and be able to adjust across the channels.

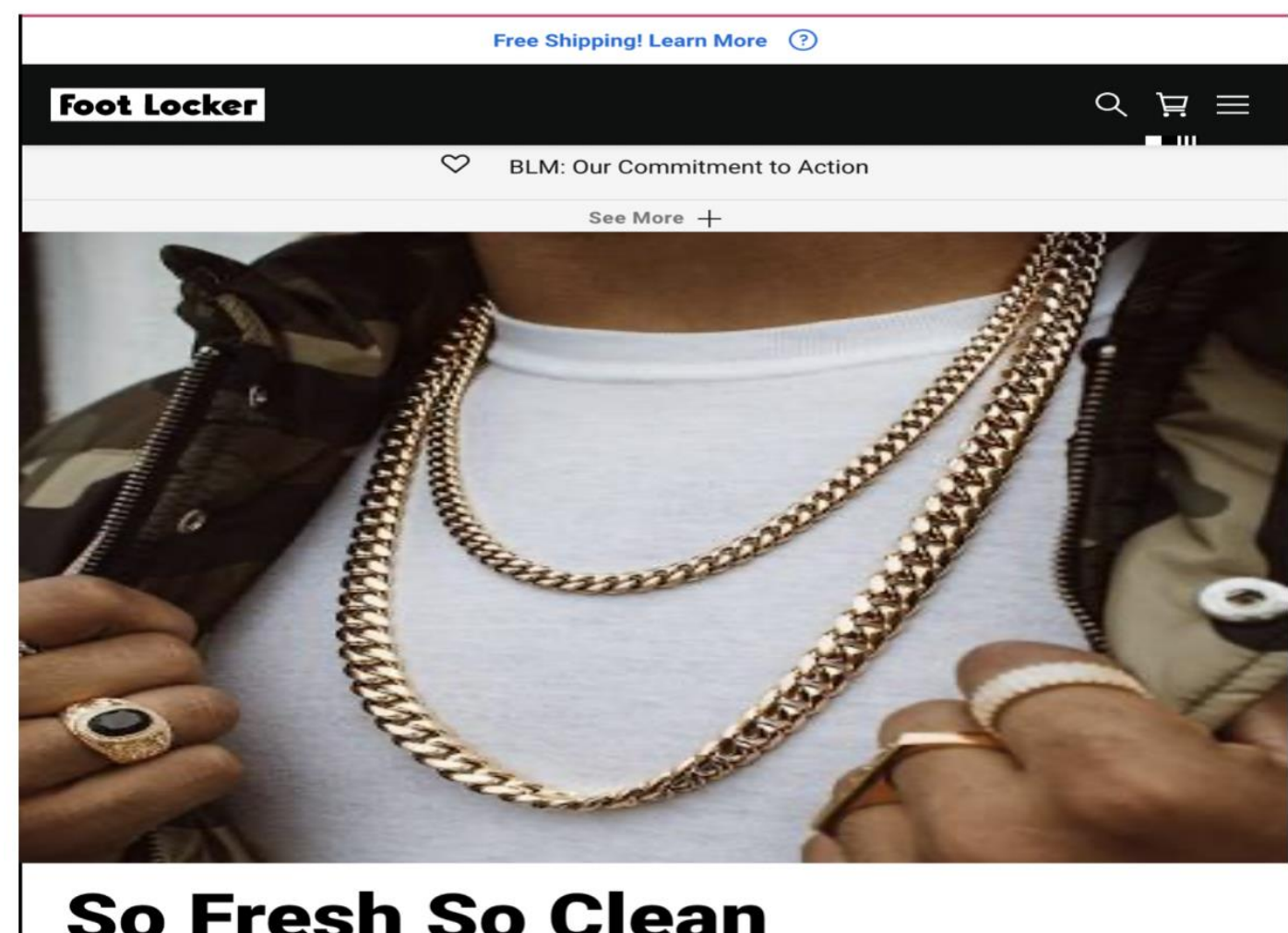

Figure 4

Proposed Foot Locker Landing Page Highlighting Jewelry 


\section{Merchandising and Global Marketing}

"Foot Locker is a leading global retailer of athletically inspired shoes and apparel." (Scrudato, 2020). Global marketing will enhance Foot Locker's product extension into jewelry and broaden their product reach. Through market research and thorough analysis, Foot Locker will have the tools they need to thrive and make Jewelry by Foot Locker successful both in the US and overseas. Part of this new strategy would be for Foot Locker to sell other brands of jewelry similar to what they do with their apparel and shoes. For their jewelry, they can sell brands like Sutton by Rhona Sutton, STEEL TIME, Esquire, and Giani Bernini.

They can also create their brand that they exclusively sell only at Foot Locker. Foot Locker can create their jewelry collection partnering with Evershiny Jewelry. They are the leading manufacturer and of jewelry in Thailand. They are also an environmentally conscious company that meets the European Union's REACH standards (Restriction, Evaluation, and Authorization of Chemicals) "which restrict hazardous substances such as nickel, lead, and cadmium in all parts of jewelry." (Evershiny, 2020). They are also a certified member of the Business Social Compliance Initiative "which is a leading supply chain management system that supports companies to drive social compliance and improvements within the factories in their global chains." (Evershiny, 2020). Evershiny works hard with stone suppliers and is sourced all over the world including Brazil, India to Madagascar. All the crystals are from Swarovski and are lead-free. They also offer various plating colors like $18 \mathrm{~K}$ Gold, $18 \mathrm{~K}$ Rose Gold, and Silver. Evershiny's product line includes necklaces, rings, earrings, bracelets, and pendants. Foot Locker's product extension will be one of kind and offer various products because of Evershiny. Stores will be supplied with new shipments every "4-8 weeks" (Evershiny, 2020) so Foot Locker will not have to worry about not having something in stock or not having fresh inventory. This will keep customers constantly coming in to see what Foot Locker has to offer. Lastly, Evershiny can ship "worldwide via FedEx, FedEx, and DHL" (Evershiny, 2020) so shipment will come fast no matter it is needed.

\section{Marketing Plan}

Endorsements: To take Jewelry by Foot Locker international, the best strategy for Foot Locker is to go the athletic route that they are best known for and use their branding to their advantage. Foot Locker is known for working with all different types of sports. So, they should collaborate with the top sport in the world which is soccer. "Association football is played by 250 million players in over 200 countries, making it the world's [most] popular sport." (Das, 2020). It is watched all over the world: Europe, Africa, and Asia. Foot Locker can do an international campaign for the new jewelry line that will be featured on TV, billboards in major global cities, social media, the Foot Locker website, and in sports stadiums. They certainly should promotions, advertising, and social media with FIFA and the World Cup because this is the most-watched international event. Foot Locker should try to secure the endorsement for this jewelry assortment with Lionel Messi, the most well-known player internationally. Lionel Andres Messi is an Argentinian soccer player and is the second-highest-paid athlete in the world. "Messi has a deal with Adidas, Pepsi, and Gatorade." (Varty, 2019). Alternatives, or in addition to Messi, Foot Locker should approach Cristiano Ronaldo, a Portuguese soccer player and the third highest-paid athlete in 2018. "Ronaldo has a contract with Nike, Herbalife, EA Sports, and American Tourister. (Varty, 2019). Another option would be Neymar de Silva Santos Junior, a Brazilian soccer player, and the third highestpaid soccer player. "The Brazilian forward works with global sponsors including Nike Red Bull and McDonald's." (Varty, 2019). All of these soccer players have endorsements from brands that Foot Locker sells. Foot Locker could come up with a cross-branding endorsement deal that is going to benefit all the major sponsors and get their jewelry collection visibility. Once the soccer endorsements are secured and prove profitable, Foot Locker can expand to more athletics and in other major sports including basketball and baseball (just to name the top two other sports).

Industry Growth. Jewelry by Foot Locker is trying to be a player in the jewelry market. "The global jewelry market size was valued at USD 278.5 billion in 2018 and is anticipated to witness significant growth over the forecast period." (Grand View Research, 2019). The market is only going to grow and expand so that is great for Foot Locker and their company. They are not going into a declining and nonprofit market. So, this a great market for Foot Locker to go into. The only concern about the jewelry industry is that the material to make the jewelry does fluctuate so that can have an effect on costs. So, Foot Locker has to make sure that they find the right supplier and balance the cost between making the product and making a profit.

Market Segmentation: "Jewelry stores in the US generated $\$ 39.7$ billion in sales in 2018, a year over year increase of $\$ 7.3$ billion." (Polygon, 2020). These numbers are still growing because of social media trends. "Jewelry demand is price-sensitive. When the price of gold jewelry rises by $1 \%$, the quality demanded falls by $2.6 \%$ " (Longman Business, 2020). The best way to meet our male demographic is to target them and let them know our products have a great quality for a great price. Foot Locker will look at their competition and see the right price for them and the customer. "Many people use jewelry solely as a fashion accent. They select their pieces based on how well they match particular clothes or outfits." (Mountz Jewelers, 2016). In today's society, people are more open to expressing themselves with jewelry especially men. 
Jewelry such as bracelets and earrings that wear just worn by women are worn by men too.

Market Climate. "Consumer appetite for jewelry, which was dampened by the global recession, now appears more voracious than ever.'(Dauriz, Remy, Tochtermann, 2014). Trends and Social Media have made more and more consumers want to express themselves with some form of jewelry. Jewelry can mean and represent different things to different people. It can represent wealth security, status, a rite of passage, and even certainly a fashion statement. It all depends on the individual wearing it. In today's times, customers including men are wearing more and more jewelry to express their style and who they are. This is a perfect time for Jewelry by Foot Locker to come out with their collection. Foot Locker is already known for selling apparel and shoes that customers proudly wear-adding jewelry as part of the merchandise they sell.

Jewelry by Foot Locker would become part of a strong brand that has established a name for themselves over the years. Foot Locker is an athletic retailer that has maintained strong relationships with various brands. "For years, Foot Locker has maintained a close relationship with Nike." (Scrudato, 2015). Foot Locker can make negotiations and deals for them to showcase their new jewelry collection. The connections that Foot Locker has can open so many doors. Another strength is that jewelry is the new trend and that everyone especially men is wearing it with their outfits. This investment that Foot Locker is going to take part in is only going to be profitable and bring more people into their stores and on their online applications. Another strength that opening this business has is the barriers to entry are low. Foot Locker has the capital and known brand image to start and venture off into the jewelry industry. A weakness is that Foot Locker's location itself is losing foot traffic in their physical locations. This is because most consumers shop online to get their merchandise. This can affect Foot Locker if they build Jewelry by Foot Locker stores as well.

Some opportunities that Jewelry by Foot Locker has is they can change the jewelry industry and how they interact with customers. They can use the technology that Foot Locker has on their e-commerce to their advantage over traditional brick and mortar stores. This is a great opportunity for Foot Locker to give their jewelry collection a more interactive experience. Some threats are of course there are other known jewelers that customers already know and get their jewelry from. Foot Locker has to work twice as hard to attract consumers to their jewelry collection.

Competitor Analysis. "The ten biggest jewelry groups capture a mere $12 \%$ of the worldwide market, and only two Cartier and Tiffany \& Co are in Interbrand's ranking of the top 100 global brands. The rest of the market consists of strong national retail brands such as Christ in Germany or Chow Tai
Fook in China, and small or midsize enterprises that operate a single-branch store." (Dauriz, Remy, Tochtermann, 2014). The main jewelry competitors are Tiffany \& Co, Blue Nile, Harry Winston, Bulgari, Zale's, Chopard, Graff, and Kay Jewelers. The first main competitor Tiffany \& Co. Tiffany is a popular jewelry retailer that was founded in 1837 . The company sells silver jewelry, crystal, china, fragrances, and some leather goods. The Blue Nile is a popular online jewelry retailer and was established in 1999. "They [Blue Nile] is the largest online sellers of diamonds in the USA (Bhasin, 2019). They sell an array of jewelry such as rings, necklaces, bracelets, watches, and so on. Harry Winston "is an American jeweler who transmuted diamond into modern jewelry and watch design" (Bhasin, 2019). Harry Winston has become an image of international style and designs have high-quality craftsmanship. Bulgari is a popular luxury Italian brand that is known for its jewelry, watches, accessories, fragrances, and leather goods. "The main strength of this brand is its unique and contemporary style." (Bhasin, 2019). The company has about 230 retail locations across the world and about 4,000 employees working for them.

Zale is a known jeweler in the US with its headquarters being in Irving Texas. They have about 785 stores in the United States. They offer high-quality merchandise at a reasonable price. Chopard is a Swedish brand that makes jewelry and watches. They were founded in 1860 and their headquarters is in Geneva, Switzerland. They use creativity and state-of-the-art technology to make their merchandise. Graff is a British jeweler that is headquartered in London, UK. Graff is known for their distinct style as a jeweler. "The main strength of this company is its craft that is done by experienced craftsmen who are experts in cutting, polishing, and making the diamonds. (Bhasin, 2019). Kay Jewelers is a retailer known in the US but also the UK and Canada. Kay Jewelers was founded in 1916 and has 3,500 stores. They have a wide array of the item in their jewelry collection including earrings, necklaces, rings, bracelets, and more. Kay Jewelers has developed high brand awareness among the US and has a famous tagline "Every kiss begins with Kay." All of these jewelers are competitors because they have a stable brand image and a solid customer base. Jewelry by Foot Locker will have to position themselves against these competitors in a way that distinguishes their style and lifestyle fit relative to Foot Locker's clothing and sneaker lines.

Selected Marketing Strategy: Jewelry by Foot Locker is going to take the fashionable trendy approach when it comes to their marketing approach. They are athletic but are going to stylish with whatever the male demographic wants to wear. This is the marketing approach they should choose because they are already known for being athletic so they should stick with what they know best and just build off that. The main products of the collection will be mainly gold and silver 
chains. The collection will also include Jesus's pendants, earrings, rings, and watches. Depending on how well the collection does, the collection can have more or less merchandise. The price will all depend on market research, manufacturing, laboring, and shipping costs. The same pricing includes $\$ 220$ for the chains, $\$ 350$ for Jesus pendants, and $\$ 400$ plus for watches. If Foot Locker wants to include personalization for customers, then pricing will increase. When you're talking about the place, the jewelry collection will be promoted in all places that are connected to the Foot Locker brand. This includes in-store, online, and on their Foot Locker mobile applications.

Jewelry by Foot Locker will be heavily promoted on social media where our male demographic is on. Foot Locker can promote a consumer timeline where it will get their attention. Also, when someone is searching for jewelry on a search engine, there will be an advertisement on the side to get their attention as well. Other than social media, Jewelry by Foot Locker will be promoted on tv, billboard, and major sporting events such as the NBA and FIFA. Eventually, when the collection gets big enough different athletic celebrities can promote the brand as well. This can be from all leagues like soccer, football, golf, hockey, lacrosse, volleyball and so much more. Foot Locker can promote on all spectrums to get the collection known and attract all types of demographics. Above is an example of a short-term projection that Foot Locker would try to aim for. Foot Locker has about 800 stores, so they can sell at least 1000 gold chains throughout their stores. Inventory and pricing will change once Foot Locker does more research on what the target market is willing to pay and how much it costs to make everything. Long Term goals will be for Jewelry by Foot Locker to become a known jeweler for athletic and fashionable wear. Once the brand image, Foot Locker can increase pricing to how they see fit.

\section{Conclusion}

Jewelry by Foot Locker is a logical extension to the Foot Locker brand and is value-added from a customer's perspective. The research has indicated that male consumers are coming to Foot Locker in order to purchase one or two products but would like the opportunity to complete their entire outfit at Foot Locker. Foot Locker can become a onestop-shop for men. Longer-term, Foot Locker might want to venture into women's and children's jewelry. "The value of the jewelry market is expected to increase from about 279 billion U.S. dollars in 2018 to about 480.5 billion dollars by 2025." (O'Connell, 2020). Why wouldn't Foot Locker leverage their brand name and loyal customer base and expand into the jewelry market?

\section{REFERENCES}

ABOUT. (n.d.). EveryShiny. https://www.evershinyjewelry.com/about.

Adglow. (n.d.). E-Commerce: Men spend more than women. https://www.adglow.com/blog/pt-br/e-commerce-menspend-more-than-women.

Bhasin, H. (2019, February 8). Top 10 Pandora jewelry Competitors - Competition Analysis of Pandora. https://www.marketing91.com/top-10-pandora-jewelry-competitors/.

By Contributor, W., \& Contributor. (2020, April 07). A Brief History of Bling: Hip-Hop Jewelry Through the Ages. https://www.highsnobiety.com/p/hip-hop-jewelry/.

Das, S., Says, S., Moon, S., Says, Z., Zach, Says, T., \& Hicki. (2020, July 15). Top 10 Most Popular Sports in The World https://sportsshow.net/top-10-most-popular-sports-in-the-world/.

Dauriz, L., Remy, N., \& Tochtermann, T. (2018, January 08). A Multifaceted future: The Jewelry Industry in 2020. https://www.mckinsey.com/industries/retail/our-insights/a-multifaceted-future-the-jewelry-industry-in-2020.

Foot Locker. (2020, February 07). https://www.companieshistory.com/foot-locker/.Foot Locker (2020, February 28). Foot Locker, Inc. Reports 2019 Fourth Quarter and Full Year Results. https://www.prnewswire.com/newsreleases/foot-locker-inc-reports-2019-fourth-quarter-and-full-year-results-301013090.html.

Jewelry Culture and Symbolism Around the World. (2016, December 19). https://mountzjewelers.com/blogs/mountzjewelers/jewelry-culture-and-symbolism-around-the-world.

Jewelry Market Size, Share, Analysis: Industry Report, 2019-2025. (n.d.). https://www.grandviewresearch.com/industry-analysis/jewelry-market.

ReportBuyer. (2019, June 04). Global Sneakers Market Stood at \$ 58 billion in 2018 and is Projected to Grow at a CAGR of over 7\% during 2019-2024. https://www.prnewswire.com/news-releases/global-sneakers-market-stood-at-58-billion-in-2018-and-is-projected-to-grow-at-a-cagr-of-over-7-during-2019-2024-300861769.html. 
Murphy, I. (2015, July 09). Yes, Men do like to Shop for Clothes - on the Web. https://www.retaildive.com/news/yesmen-do-like-to-shop-for-clothes-on-the-web/401621/.

O'Connell, L. (n.d.). Topic: Foot Locker. https://www.statista.com/topics/5239/foot-locker/.

O'Connell, L. (n.d.). Topic: Jewelry market worldwide. https://www.statista.com/topics/5163/jewelry-marketworldwide/.

Price-sensitive. (n.d.). https://www.ldoceonline.com/dictionary/price-sensitive.

Smallbiztrends (2020, April 21). What Male Customers Want-Analyzing Their Shopping Behaviors. https://smallbiztrends.com/2020/02/what-male-customers-want.html.

Team, V. (2020, March 02). Top 10 Most Iconic Celebrity Shoe Collabs. https://w ww.voirfashion.co.uk/post/top-10most-iconic-celebrity-shoe-collabs.

Trade Resources. (n.d.). https://www.polygon.net/jwl/public/trade-resources/industry-reports-en.jsa.

Varty, A. (2020, January 29). Five Highest-Paid Soccer Players. https://www.investopedia.com/managing-wealth/5highestpaid-soccer-players/

Velasco, H. (2017, August 10). Foot Locker, BBDO play on 'Make an Impression' in a new campaign. https://www.thedrum.com/news/2017/08/09/foot-locker-bbdo-play-make-impression-new-campaign. 